\title{
England Batholith, NSW, Australia: Age implications for the crust
}

\author{
S.E. Shaw, R.H. Flood \\ GEMOC Key Centre, Department of Earth and Planetary \\ Sciences, Macquarie University, 2109, Australia (sshaw@els. \\ mq.edu.au; rflood@els.mq.edu.au)

\section{Heading} \\ Zircon Lu-Hf istopic data for representative plutons from the \\ five granite suites of the New England Batholith indicates a signif- \\ icant Late Proterozoic lower crustal input for all except one of the \\ suites. Earlier published oxygen (O'Neil et al.) and recently pub- \\ lished Li isotopic data (Bryant et al., 2004) support the view that \\ the two Permo-Carboniferous suites (Bundarra and Hillgrove) are \\ S-type but with $87 \mathrm{Sr} / 86 \mathrm{Sr}$ ratios that are lower than those of \\ Lachlan Fold Belt S-types and that of the three Permo-Triassic \\ metaluminous suites, one, the Clarence River, is an isotopically \\ primitive I-type, one, the Moonbi, is a more evolved I-type and \\ the third, the Uralla, has isotopic and mineralogical characteris- \\ tics transitional between I-type and S-type. \\ New ${ }^{176} \mathrm{Hf} / \mathrm{Hf}^{177}$ data from single zircon grains obtained using \\ the methods and elegant correction procedures in Griffin et al. \\ (2000) show that only the Clarence River suite has $T_{D M}$ model \\ ages close to the emplacement ages. Zircon data for the other four \\ suites suggests the crustal component underlying of the New Eng- \\ land Batholith could be as old as Late Proterozoic. The data are \\ consistent with the initiation of the Tasman Fold Belt System, of \\ which New England is part, around 830 and $730 \mathrm{Ma}$.
}

\section{References}

Bryant, C.J., Chappell, B.W., Bennett, V.C., McCulloch, M.T., 2004. Trans. Roy. Soc. Edin. 95, 199-214.

Griffin, W.L., Xiang Wang, Jackson, S.E., Pearson, N.J., O'Reilly, S.Y., Xisheng Xu, Xinmin Zhou, 2000. Lithos 61, 237-269.

O'Neil, J., Shaw, S.E., Flood, R.H., Contrib. Mineral Petrol. 62 313-328. 